\title{
Effect of Temperature Shock on Soybean Microspore Embryogenesis
}

\author{
Ana Paula de Moraes $^{1}$, Maria Helena Bonadese-Zanettini ${ }^{1}$, Sídia Maria Callegari-Jacques ${ }^{2}$ \\ and Eliane Kaltchuk-Santos ${ }^{1 *}$ \\ ${ }^{1}$ Departamento de Genética; Universidade Federal do Rio Grande do Sul; eliane.kaltchuk@ufrgs.br; C. P. 15053; \\ 91501-970; Porto Alegre - RS - Brazil. ${ }^{2}$ Departamento de Estatística; Universidade Federal do Rio Grande do Sul; \\ Porto Alegre - RS - Brazil
}

\begin{abstract}
In this study the effect of cold and heat shock on androgenetic induction in soybean anther culture was tested. Anthers of soybean were subjected to 4 and $33^{\circ} \mathrm{C}$, while the anthers used for control were maintained at $25^{\circ} \mathrm{C}$. Cytological analysis done during the 30 days of culture showed that frequencies of symmetrical binucleated and multicellular pollen grain did not differ among temperature treatments. Multicellular pollen grain could be formed by symmetrical division, as well as by assymetrical division. In relation to the embryo induction, the results of the treatments did not differ too. These results suggested that these treatments did not induce a sporophytic pathway in soybean.
\end{abstract}

Key words: Anther culture, soybean, androgenesis, symmetrical mitosis, temperature shock, stress

\section{INTRODUCTION}

The formation of embryos and haploid plants from microspores represents a fundamental switch in development from normal gametophytic to sporophytic pathway. This phenomenon in which microspores change their ontogenetic route is called androgenesis and it was firstly reported by Guha and Maheshwari (1964). These researchers verified the formation of embryos on surface of cultured anthers of Datura innoxia. Since then, microspore embryogenesis has been reported in more than 200 species of angiosperms (Indrianto et al., 1999). Double haploid plants obtained from anther culture are increasingly used in plant breeding for production of homozygous lines, but its application has been limited in many species mainly because androgenetic mechanism is largely unknown.

Inductive stress treatment has been identified as the major trigger in inducing microspore and pollen grain embryogenesis for many plants. This inductive stress treatment has an influence in the first sporophytic mitosis. Studies have shown that in several species the first division is symmetrical in androgenetic embryos (Fan et al. 1988; Zaki and Dickinson, 1990, 1991, 1995). According to these authors, symmetrical division is a key step to subsequent pollen embryogenesis.

Then, pollen grains follow rapid cell divisions and a morphogenetic process, closely resembling zygotic embryogenesis, resulting in haploid plants. Four stress treatments have been shown to induce microspore embryogenesis: cold shock, heat shock, carbohydrate and nitrogen starvation and

\footnotetext{
* Author for correspondence
} 
colchicine. Heat shock has been reported to increase the embryogenic route in several plants like wheat (Touraev et al., 1996c), tobacco (Touraev et al., 1996a and 1996b) and Brassica (Telmer et al., 1995; Binarova et al., 1997; Custers et al., 1994) while the cold shock and starvation induced microspore embryogenesis in maize, wheat, barley and rice (Indrianto et al., 1999).

The developmental stage of microspore at the time of culture initiation is of crucial importance, with late vacuolated microspore to early bicellular pollen grain being the responsive stages to heat stress (Pechan and Keller, 1988). Since not all microspores respond to the inductive treatment, the cultures always contain a high percentage of gametophytic pollen grain.

This paper reports the effect of two inductive stress treatments, cold $\left(4^{\circ} \mathrm{C}\right)$ and heat $\left(33^{\circ} \mathrm{C}\right)$ shock, in six soybean cultivars. The formation of embryo-like structure and cytological characteristics were observed.

\section{MATERIAL AND METHODS}

\section{Plant material}

Soybean (Glycine $\max$ (L.) Merrill; 2n=40) cultivars IAS 5, Bragg, Década, RS 7, BR 4, and BRS 133 field-grown were used as a source of inflorescences.

\section{Anther culture}

Floral buds of 3.0-3.5 mm in length containing uninucleate microspores were collected and kept at $4^{\circ} \mathrm{C}$ for $12 \mathrm{~h}$. The surface of the buds was sterilized with $70 \%$ ethanol for $30 \mathrm{~s}, 2 \% \mathrm{NaOCl}$ solution with a trace amount of detergent for $12 \mathrm{~min}$ and then rinsed three times in sterile distiled water.

\section{Embryo induction}

Anthers were cultured in induction medium I - B5 basal medium (Gamborg et al., 1968) enriched with 16 organic compounds - supplemented with Yeung's amino acids (Yeung and Sussex, 1979), 9\% sucrose, $0.25 \%$ Phytagel $^{\circledR}, 2.0 \mathrm{mgL}^{-1}$ 2,4-D and $0.5 \mathrm{mgL}^{-1}$ BAP. For each cultivar, eighteen small Petri dishes with induction medium I were used, six dishes for treatment $\left(4,25\right.$ and $\left.33^{\circ} \mathrm{C}\right)$. Six cultivars were used, totalizing 36 dishes in each temperature. Fifty-five anthers were inoculated for dish. The dishes were incubated during four days in the dark. After this period, the cultures were maintained at $25^{\circ} \mathrm{C}$ under $16 \mathrm{~h}$ photoperiod of 22.5 $\mu$ mol. $\mathrm{m}^{-2} . \mathrm{s}^{-1}$ provided by fluorescent light and subcultured every 4 weeks. After 8 weeks, the anthers were transferred to an induction medium II (medium I with $1.0 \mathrm{mgL}^{-1}$ 2,4-D and $1.0 \mathrm{mgL}^{-1}$ BAP) with a subculture on the same fresh medium every 4 weeks.

\section{Embryos maturation}

On the $75^{\text {th }}$ day, half of embryogenic calli were transferred to MSM6 (Finer and McMullen, 1991) and the other half, to induction medium II. After 30 days, calli and embryos were counted, separated, and the histodifferentiated transferred to MSO (MS salts, B5 vitamins, 3\% sucrose, $0.25 \%$ Phytagel $^{\circledR}, \mathrm{pH}$ 5.8) medium.

\section{In vitro Analysis}

After 60 days of culture the anthers were classified into three classes: no responsive anthers, rough calli and embryogenic calli (green, smooth and bright calli).

\section{Cytological Analysis}

Five anthers per Petri dish were fixed in ethanol:glacial acetic acid (3:1) at 0,15 and 30 days of culture for cytological analysis. The anthers were squashed in propionic carmine on glass slides and sealed under cover slips with bee's wax. Microspores were staged and classified under a Zeiss Axioplan Universal microscope.

\section{Statistical Analysis}

Data on total calli (rough and embryogenic calli) and embryogenic calli formation were compared among treatments and cultivars with the KruskalWallis (KW) test, followed by Dunn's nonparametric multiple comparisons (Zar, 1999).

Data on binucleate and multicellular pollen grains was $\log$ transformed and a three-way factorial analysis of variances was conducted to evaluate the effects of genotype (6 cultivars), temperature $\left(4,25\right.$ and $\left.33^{\circ} \mathrm{C}\right)$, days of culture $(0,15$ and 30$)$ and interactions in the proportion of binucleate and multicellular pollen grain. As a significant heterogeneity among variances were found, the Welch's test was performed to check the significance of the interaction effects, followed by Dunnett's-T3, a test for multiple comparisons that do not assume equal variances. 


\section{RESULTS}

\section{Embryogenic and total calli formation}

The number of embryogenic as well as of total (rough plus embryogenic) calli formed in each Petri dish was avaliated for each treatment $(\mathrm{N}=36)$, not matching distinction among cultivars (Table 1). The avarege number of embryogenic calli varied from 2.7 to 4.1 , but the differences among temperatures were not statistically significant $\left(\chi_{\mathrm{KW}}^{2}=4.251 ; \mathrm{df}=2 ; \mathrm{p}=0.119\right)$. The avarege for the total calli formation did not vary among temperatures either $\quad\left(\chi^{2}{ }_{\mathrm{KW}}=1.423 ; \mathrm{df}=2 ; \mathrm{p}=0.49\right)$. On the other hand, significant differences, independent of treatment, were found both for the number of embryogenic $\left(\chi_{\mathrm{KW}}^{2}=32.251 ; \mathrm{df}=5\right.$; $\mathrm{p}<0,001)$ and the total $\left(\chi_{\mathrm{Kw}}^{2}=14.517 ; \mathrm{df}=5\right.$; $\mathrm{p}=0.013)$ calli produced. BRS 133 showed the lowest induction frequency of embryogenic calli in comparison with other cultivars (Fig. 1). The same pattern, however, was not observed for the total calli production: BR 4 produced significantly more calli than IAS 5 and Bragg; the other cultivars did not present statistical differences in relation to these three cultivars (Fig. 2).

The embryos formed until the $60^{\text {th }}$ day of culture showed high variability in their morphology during development. Many embryos were partially or completely fused (Fig. 3). Several of these embryos were not able to develop into a plantlet and just a small number survived in culture during many months. These structures were maintained in the MSO, nevertheless, part of them eventually blackened and died. When transferred into MSO medium containig $1 \%$ sucrose, the plantlets further developed. A complete plantlet with leaves was observed after the $80^{\text {th }}$ day of culture (Fig. 3c). Chromosome counts in this plantlet showed the expected haploid $(2 n=20)$ condition (Fig. $3 d)$.

Table 1: Avarege ( \pm standard deviation) number of embryogenic and total calli formed by soybean anthers (six cultivars) mantained at three different temperature conditions ( $\mathrm{N}=36$ dishes for treatment).

\begin{tabular}{c|cc}
\hline Temp. & Number of embryogenic calli & Number of total calli formation \\
\hline${ }^{\circ} \mathbf{C}$ & Avarege \pm SD & Avarege \pm SD \\
\hline 4 & $2.9 \pm 3.5$ & $29.3 \pm 4.3$ \\
25 & $4.1 \pm 2.9$ & $29.9 \pm 3.6$ \\
33 & $2.7 \pm 2.0$ & $29.2 \pm 4.4$ \\
\hline
\end{tabular}

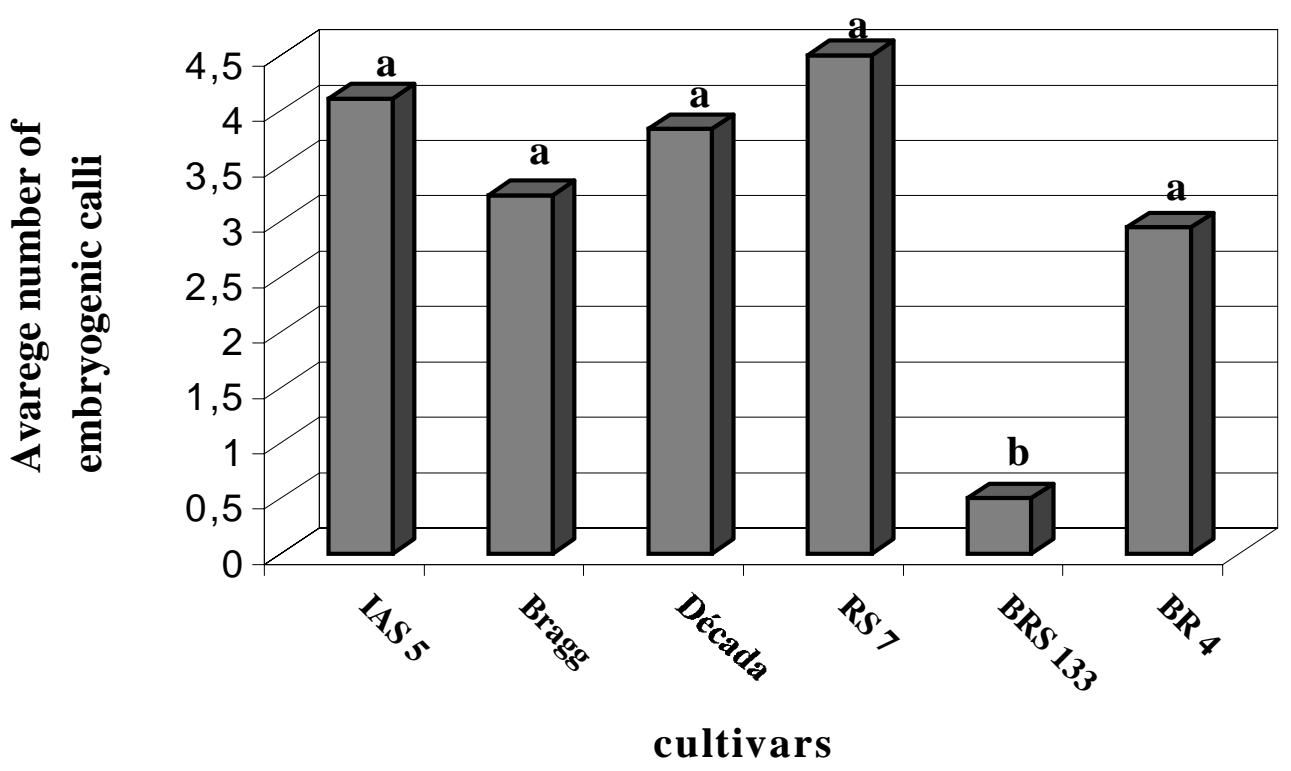

Figure 1 - Avarege number $(\mathrm{N}=18)$ of embryogenic calli produced per cultivar, on the 60th day of culture. Avarege followed by the same letter do not differ significantly $(a=0,05)$. 


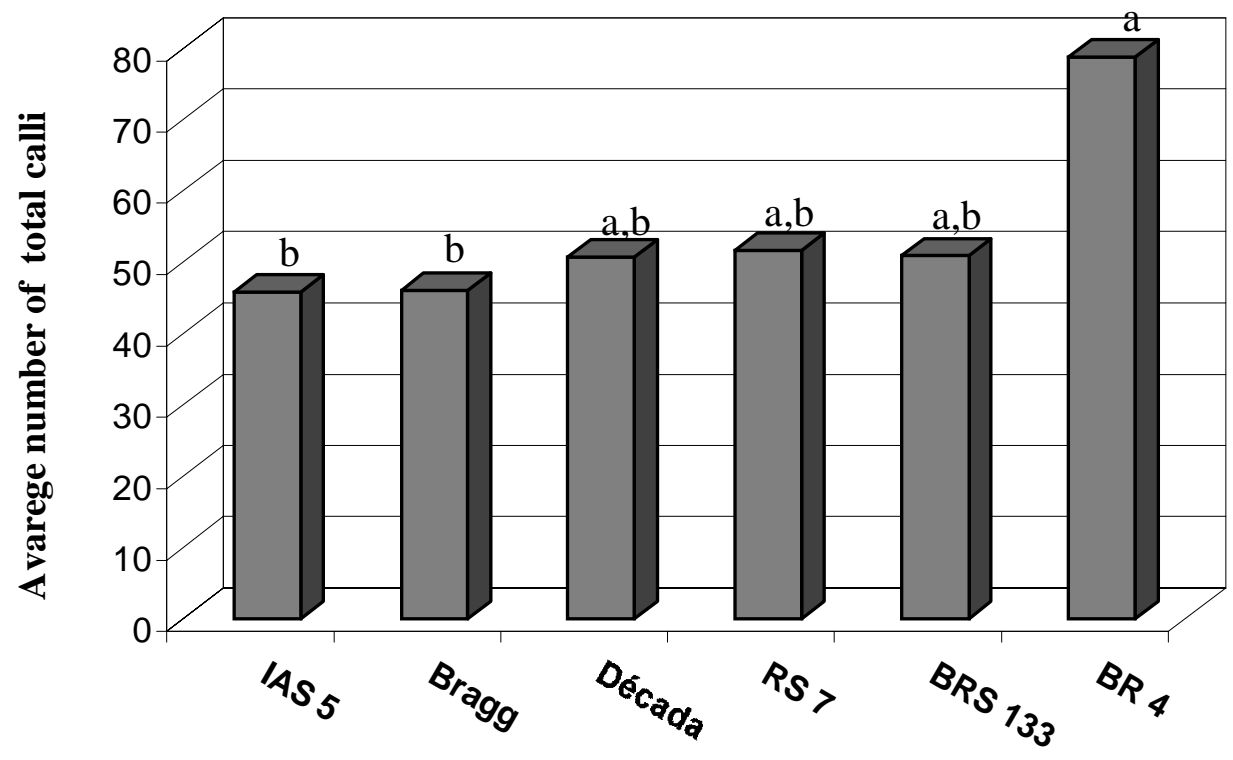

Cultivars

Figure 2 - Avarege number $(\mathrm{N}=18)$ of total calli produced per cultivar, on the 60th day of culture. Avarege followed by the same letter do not differ significantly $(a=0,05)$.

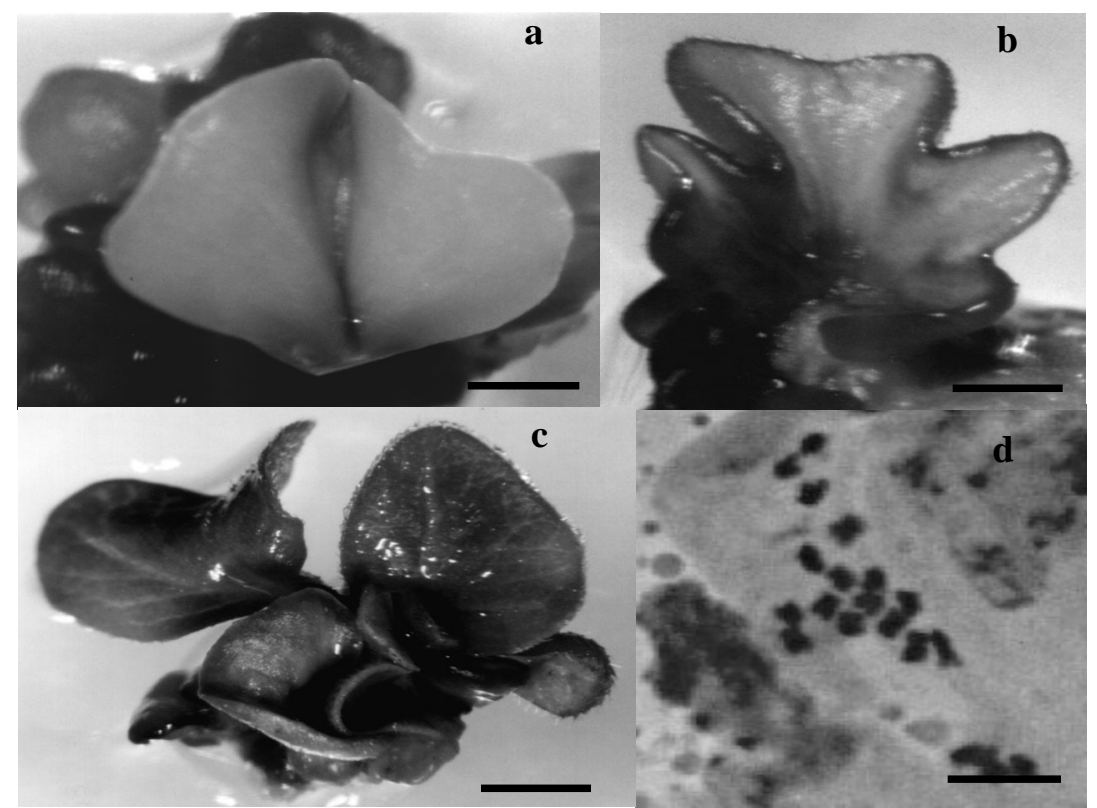

Figure 3 - Structures formed in culture: $a$ and $b$ - fused cotyledons (bars=1 mm), c- plantlet formed from embryo (bar=1 cm), d- haploid cell with $2 \mathrm{n}=20$ (bar=10 $\mu \mathrm{m})$.

\section{Cytological analysis}

In order to investigate whether a heat or a cold shock treatment would be effective to induce the formation of binucleated symmetrical and multicellular pollen grains in soybean (Fig. 4), both with androgenetic potential, two $3 \times 3 \times 6$ factorial analysis of variance was performed. Two and three factor interactions were considered besides the main effects temperature, days of culture and cultivars. As the three factors 
interaction was statistically significant for both variables $(\mathrm{F}=4.91, \mathrm{p}<0.0001$ and $\mathrm{F}=1.91, \mathrm{p}=0.014$ for symmetrical and multicellular pollen grains, respectively), treatments could not be compared without considering cultivars and days of culture. Therefore, the effects of cultivars and temperature (as well as its interactions) were analysed at each day of culture separately.

Differences were detected only at day 15 of culture for symmetrical binucleated and multicellular pollen grains (Table 2). Cultivar RS
7 incubated at 25 and $33^{\circ} \mathrm{C}$ showed more symmetrical binucleate pollen grains than Década incubated at $4^{\circ} \mathrm{C}$, other differences being not significant. For multicellular pollen grains, RS 7 incubated at $25^{\circ} \mathrm{C}$ showed higher frequencies of multicellular pollen formation than Bragg/Década incubated at $4^{\circ} \mathrm{C}$, IAS $5\left(33^{\circ} \mathrm{C}\right)$ and Década/BR 4 incubated at $25^{\circ} \mathrm{C}$, which presented the same average number of multicellular pollen grains $(0-0.2)$.

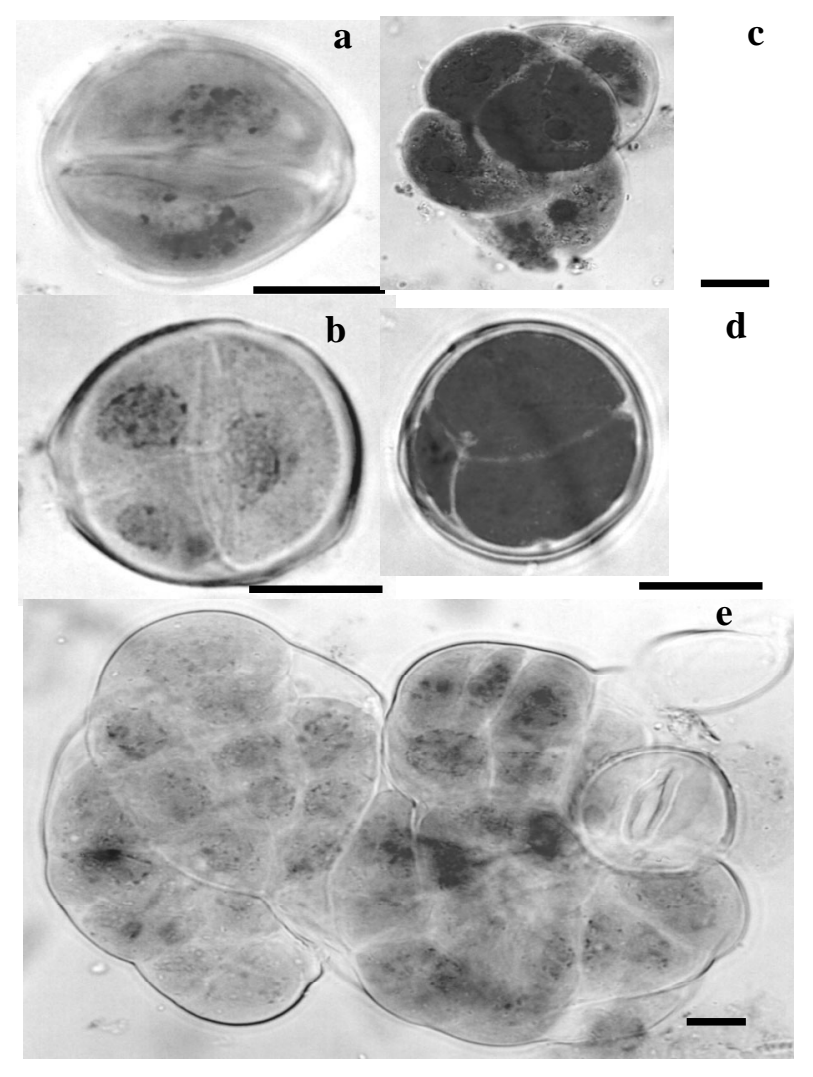

Figure 4 - Symmetrical and multicellular soybean pollen grains. a- symmetrical pollen grain; b, $\mathrm{c}$ and e- multicellular pollen grain; $d$ - multicellular pollen grain with two vegetative and one generative cell. $(\mathrm{bars}=10 \mu \mathrm{m})$. 
Table 2 - Average ( \pm standard deviation; $N=6$ ) of the number of binucleated and multicellular pollen grains at day 15 of culture.

\begin{tabular}{lr|r|r}
\hline Cultivars & Temp. & Binucleate pollen grains & Multicellular pollen grains \\
\hline \multirow{2}{*}{ IAS 5 } & ${ }^{\circ} \mathrm{C}$ & Mean $\pm \mathrm{SD}$ & Mean $\pm \mathrm{SD}$ \\
& 4 & $5.8 \pm 8.0 \mathrm{AB}$ & $0.3 \pm 0.8 \mathrm{AB}$ \\
& 25 & $2.0 \pm 5.0 \mathrm{AB}$ & $1.8 \pm 4.5 \mathrm{AB}$ \\
Bragg & 33 & $1.0 \pm 1.7 \mathrm{AB}$ & $0.2 \pm 0.4 \mathrm{~A}$ \\
& 4 & $1.7 \pm 1.4 \mathrm{AB}$ & $0 \pm 0 \mathrm{~A}$ \\
Década & 25 & $1.8 \pm 3.6 \mathrm{AB}$ & $1.8 \pm 2.4 \mathrm{AB}$ \\
& 33 & $1.8 \pm 1.8 \mathrm{AB}$ & $0.8 \pm 1.0 \mathrm{AB}$ \\
RS 7 & 4 & $0.7 \pm 0.8 \mathrm{~B}$ & $0 \pm 0 \mathrm{~A}$ \\
& 25 & $0.8 \pm 1.0 \mathrm{AB}$ & $0.2 \pm 0.4 \mathrm{~A}$ \\
& 33 & $0.8 \pm 1.0 \mathrm{AB}$ & $0.8 \pm 1.2 \mathrm{AB}$ \\
BRS 133 & 4 & $17.2 \pm 19.0 \mathrm{AB}$ & $10 \pm 17.3 \mathrm{AB}$ \\
& 25 & $8.5 \pm 7.1 \mathrm{~A}$ & $2.7 \pm 1.2 \mathrm{~B}$ \\
& 33 & $4.8 \pm 1.9 \mathrm{~A}$ & $0.8 \pm 0.7 \mathrm{AB}$ \\
& 4 & $5.7 \pm 4.6 \mathrm{AB}$ & $3.3 \pm 3.3 \mathrm{AB}$ \\
& 25 & $3.7 \pm 5.6 \mathrm{AB}$ & $3.3 \pm 4.0 \mathrm{AB}$ \\
& 33 & $3.2 \pm 2.8 \mathrm{AB}$ & $0.8 \pm 1.0 \mathrm{AB}$ \\
& 4 & $10.7 \pm 7.7 \mathrm{AB}$ & $4.3 \pm 7.4 \mathrm{AB}$ \\
& 25 & $5.0 \pm 4.5 \mathrm{AB}$ & $0.2 \pm 0.4 \mathrm{~A}$ \\
& 33 & $1.7 \pm 1.5 \mathrm{AB}$ & $0.8 \pm 1.6 \mathrm{AB}$ \\
\hline
\end{tabular}

Means followed by the same letter do not differ significantly $(\alpha=0,05)$.

\section{DISCUSSION}

Data obtained in the present study showed that embryogenic calli formation obtained after 4 days at 4 and $33^{\circ} \mathrm{C}$ did not differ from the control. Keller and Armstrong (1979) tested a treatment at 30 and $35^{\circ} \mathrm{C}$ in Brassica campestris. The first treatment decreased embryo yield, but the second stimulated the frequency of embryogenesis. Smýkal (2000) showed that in B. napus, two conditions were important to trigger embryogenesis: a) in vitro temperature should be near to the physiological limit of the plant and b) temperature of microspores in vitro should be $10-12^{\circ} \mathrm{C}$ higher than the temperature of donor plant. In the present study, only one high temperature, $33^{\circ} \mathrm{C}$, was tested which might not be sufficiently elevated to increase the frequency of embryogenesis. In spite of a great variability in the morphology of embryos formed in vitro, they resembled the somatic ones induced in high 2,4-D medium from immature cotyledons (Buchheim et al., 1989; Santos, 1997). A previous study showed that putative androgenetic embryos of soybean were histologically similar to zygotic embryos (Kaltchuk-Santos et al., 1997).

According to some authors, induction of cell division is an independent process in the determination of embryogenesis. Touraev et al. (1996a) showed that multicellular structures could be formed after asymmetric mitosis indicating that symmetry of microspore in vitro is not essential for embryogenic induction. In the present analysis it was observed that multicellular structures were formed from vegetative cell after asymmetric mitosis (Fig. 4d). Our results did not provide any evidence to conclude what was the best temperature to induce symmetrical divisions 
and/or multicellular pollen grains formation in soybean, since it detected interactions between cultivars, treatments and days of culture.

\section{ACKNOWLEDGEMENT}

This study was supported in part by $\mathrm{CNPq}$, FAPERGS and PROPESQ.

\section{RESUMO}

Neste estudo foram testados os efeitos do choque térmico na indução androgenética em cultura de anteras de soja. Parte das anteras formam submetidas ao choque térmico de 4 ou $33^{\circ} \mathrm{C}$, enquanto as anteras controle formam mantidas a $25^{\circ} \mathrm{C}$. Análises citológicas formam realizadas ao longo dos 30 primeiros dias de cultura mostrando que a frequiência de grãos de pólen binucleados simétricos e multinucleados não difere entre os tratamentos e que os grãos de pólen multinucleados podem ser formados tanto a partir de uma mitose simétrica inicial como após uma mitose assimétrica. Em relação à indução embriogênica, os tratamentos também não diferem. Estes resultados sugerem que o tratamento de choque térmico não induz a rota esporofítica nos micrósporos de soja.

\section{REFERENCES}

Binavora, P.; Hause, G.; Cenklová, V.; Cordewener, J. H. G. and; Van Lookeren Campagne, M. M. (1997), A short severe heat shock is required to induce embryogenesis in late bicellular pollen of Brassica napus L. Sex. Plant Reprod.,10, 200-208.

Buchheim, J. A.; Colburn, S. M. and Ranch, J. P. (1989), Maturation of soybean somatic embryos and the transition to plantlet growth. Plant Physiol., 89, 768-775.

Custers, J. B. M.; Cordewener, J. H. G.; Nöllen, Y.; Dons, H. J. M. and van Lookeren Campagne, M. M. (1994), Temperature controls both gametophytic and sporophytic development in microspore culture of Brassica napus. Plant Cell Reports, 13, 267-271.

Fan, Z.; Armstrong, K. C. and Keller, W. A. (1988), Development of microspores in vivo and in vitro in Brassica napus L. Protoplasma, 147, 191-199.
Finer, J. J. and McMullen, M. D. (1991), Transformation of soybean via particle bombardment of embryogenic suspension culture tissues. In Vitro Cell. and Developmental Biology, 27P, 175-182.

Gamborg, O. L.; Miller, R. A. and Ojima, K. (1968), Nutrient requirements of suspension culture of soybean root cells. Exp. Cell. Res., 50, 151-158.

Guha, S. and Maheshwari, S. C. (1964), In vitro production of embryos from anthers of Datura. Nature, 204, 497.

Indrianto, A; Herbele-Bors, E. and Touraev, A. (1999), Assessment of various stresses and carbohydrates for their effect on the induction of embryogenesis in isolated wheat microspores. Plant Science, 143 : (1), 71-79.

Kaltchuk-Santos, E.; Mariath, J. E.; Mundstock, E. and Zanettini, M. H. B. (1997), Cytological analysis of early microspore divisions and embryo formation in cultured soybean anthers. Plant Cell, Tissue and Organ Culture, 49, 107-115.

Keller, W. A. and Armstrong, K. C. (1979), Stimulation of embryogenesis and haploid production in Brassica campestris anther cultures by elevated temperature treatments. Theorical and Applied Genetics, 55, 65-67.

Pechan, P. M. and Keller, W. A. (1988), Identification of potentially embryogenic microspores in Brassica napus. Physiol. Plant, 74, 377-384.

Santos, K. G. B. (1997), Embriogênese somática em soja (Glycine max (L.) Merrill): efeito do genótipo, do etileno e ontogenia dos embriões. Dissertação (Mestrado em Genética), Universidade Federal do Rio Grande do Sul, Rio Grande do Sul, Brasil.

Smýkal, P. (2000), Pollen embryogenesis - the stress mediated switch from gametophytic to sporophytic development. Current status and future prospects. Biologia Plantarum, 43 : (4), 481-489.

Telmer, C. A., Newcomb, W. and Simmonds, D. H. (1995), Cellular changes during heat shock induction and embryo development of cultured microspores of Brassica napus cv. Topas. Protoplasma, 185, 106-112.

Touraev, A.; Ilham, A.; Vicente, O. and Heberle-Bors, E. (1996a), Stress as the major signal controlling the developmental of tobacco microspores: towards a unified model of induction of microspore/pollen embriogenesis. Planta, 200, 144-152.

Touraev, A.; Ilham, A.; Vicente, O. and Heberle-Bors, E. (1996c), Stress-induced microspore embryogenesis in tobacco: an optimized system for molecular studies. Plant Cell Reports, 15, 561-565.

Touraev, A.; Indrianto, A.; Wratschko, I.; Ilham, A.; Vicente, O. and Heberle-Bors, E. (1996b), Efficient microspore embryogenesis in wheat (Triticum aestivum L.) induced by starvation at hight temperature. Sex. Plant Reprod., 9, 209-215.

Yeung, E. C. and Sussex, I. M. (1979), Embryogeny of Phaseoleus coccineus: the suspensor and the growth of the embryo-proper in vitro. Z. Pflanzenphysiol., 91, 423-433. 
Zaki, M. A. M. and Dickinson, H. G. (1990), Structural changes during the first divisions of embryos resulting, from anther and free microspore culture in Brassica napus. Protoplasma, 156, 149-162.

Zaki, M. A. M. and Dickinson, H. G. (1991), Microsporederived embryos in Brassica: the significance of division symmetry in pollen mitosis I to embryogenic development. Sex. Plant Reprod., 4, 48-55.

Zaki, M. A. M. and Dickinson, H. G. (1995), Modification of cell development in vitro: the effect of colchicine on anther and isolated microspore culture in Brassica napus. Plant Cell, Tissue and Organ Culture, 40, 255-270.

Zar, J. H. (1999), Biostatistical Analysis. New Jersey : Prentice Hall. 